\title{
ADOLESAN BIR KIZDA AKSESUAR MEME: NADIR BIR AKSILLER KITLE OLGUSU
}

\author{
Accessory Breast in an Adolescent Girl: A Rare Case of \\ Axillary Mass
}

Mustafa Yaşar Özdamar ${ }^{1}$, Faruk Atabey², Işın Soyuer ${ }^{3}$

\section{ÖZET}

${ }^{1}$ Bozok Üniversitesi Tip Fakültesi, Çocuk Cerrahisi Anabilim Dali, Yozgat

${ }^{2}$ Özel Modern Dünya Hastanesi Radyoloji Bölümü,

Kayseri

${ }^{3}$ Erciyes Üniversitesi Tip Fakültesi, Patoloji Anabilim Dalı, Kayseri

Mustafa Yaşar Özdamar, Yrd.Doç.Dr. Faruk Atabey, Uzm. Dr. Işın Soyuer, Prof. Dr.

iletişim:

Mustafa Yaşar Özdamar Bozok Üniversitesi Tip Fakültesi. Adnan Menderes Bulvarı. No:44 Yozgat Tel: 5062418001 e-mail: mustafayasarozdamar@gmail.com

Geliş tarihi/Received:08.02.2014 Kabul tarihi/Accepted:25.04.2014

Bozok Tip Derg 2014,4(2):71-4 Bozok Med J 2014;4(2):71-4
Adolesan kızlarda aksesuar meme görülmesi nadir bir durumdur. Aksesuar meme dokusu, fonksiyonel olarak normal meme dokusu ile benzerdir ve benzer değşikliklerle beningn veya malin hastalıklara maruz kalabilir. Çalışmamızda 12 yaşında sağ aksillasında yumuşak kitlesi olan bir kız hastayı sunduk. Ayrıca, böyle bir hasta için tedavi seçimini irdeledik. Muayenede sağ aksillada yaklaşık $5 \mathrm{~cm}$ ve ultrasonografide yaklaşık $1 \mathrm{~cm}$ 'lik şüpheli kitle tespit ettik. Eksizyonel biopside aksesuar meme dokusu ve fibrokistik hastalık saptandı. Sonuç olarak; aksesuar meme dokusunun, adolesan kızlardaki aksiller kitlede, ayırıcı tanı ve uygun tedavi açısından akılda bulundurulması vurgulandı.

Anahtar kelimeler: Meme bozukluklar; Adolesan, Kızlar.

\section{ABSTRACT}

Accessory breast is a rare condition seen in adolescent girls. Accessory breast tissue is functionally analogous to normal mammary gland and it can be exposed to the same alterations or diseases which are benign or malignant. We presented here a 12 -years- old girl with a soft mass in her right axilla in our case. Furthermore, we investigated the selection of treatment for such a patient. We detected a nearly $5 \mathrm{~cm}$ mass in right axilla on physical examination and a nearly $1 \mathrm{~cm}$ suspicious mass on ultrasonographic examination. It was revealed accessory breast tissue and fibrocystic disease in exicisional biopsy. As a result, It was emphasized that accessory breast tissue should be kept in mind for the axillary mass of adolescent girls in terms of a differential diagnosis and treated properly.

Keywords: Breast disorders; Adolescent, Girls. 


\section{Giriş}

Aksesuar meme dokusu inguinal bölge ile aksilla arasındaki pirimitif embriyonik süt çizgisi boyunca olan bir bölgede bulunur. Normal embriyonik gelişimden rezidü olarak kalan bu doku, tüm kadın ve erkek populasyonun \%2-6' sında bulunur. Embriyonik meme dokusu, süt çizgisindeki toraksta olan kısmı hariç oblitere olur. Böylece toraksta bir areola ile meme başı oluşur (1-4). Polimasti, genellikle areola ve meme başı olmadan aksesuar meme olarak oluşur (5). Kadın hastalarda aksesuar memenin farkedilmesi genellikle emzirme ve hamilelik dönemlerinde olur. Adolesan kızlarda ise menarş ile birlikte başalayan ve menstrüel sikluslarda belirginleşen aksesuar meme bölgesinde ağrı ,şişlik gibi şikayetlerle ortaya çıkar (6). Literatürde, yüz bölgesi dahil olmak üzere ekstra yerleşimli posterior boyun, göğüs, kalça, vulva, kalça, omuz, posterior-lateral uyluk, perine ve sırt orta hattınta meme dokusu tespit edilmiş ve ektopik yada aksesuar(aberran) meme olarak isimlendirilmiştir. Aksesuar meme embriyopatogenezinde süt çizgisinin yanlış yerleşimi suçlanmıştır. Aksesuar meme tanıda belirsizlik, patolojik endişe, kozmetik engelin kaldırılması gibi sebepler yoksa tedavi gerektirmeyebilir (7). Literatürdeki olgularda hastaların çoğu kozmetik nedenlerden dolayı aksesuar memenin çıkarılmasını istemiştir $(8,9)$. Literatürde aksesuar memenin klinik olarak yanlış teşhisler aldığıda görülmüştür: lipoma, sebase kisti, lenfadenit ve lenfatik malformasyon gibi $(10,11)$. Bizim olgumuzda ultrasonografi ile tam tanınamasa da, aksiller bir kitle endikasyon dahilinde, cerrahi olarak başarılı şekilde tedavi edildi. Çıkarılan kitlenin histopatolojisinde memenin fibrokistik hastalığı ile uyumlu meme dokusu olduğu tespit edildi.

\section{OLGU SUNUMU}

12 yaşında bir kız hasta, çocuk cerrahisi polikliniğimize sağ aksiller bölgede son günlerde giderek artan şişlik, hareketle koltuk altında ağrı şikayeti ile başvurdu. Bu şişlik, bir yıl önce menarş ile artmaya ve hastanın günlük aktivitelerini de kısıtlamaya başlamış. Menstruasyon dönemlerinde şişlikte artma olmuyormuş. Hastanın fizik muayenesinde sağ aksillada sınırları belli olmayan, yumuşak, palpasyonda ağrısız, yaklaşık $5 \mathrm{~cm}$ lik kitle vardı (Resim 1).

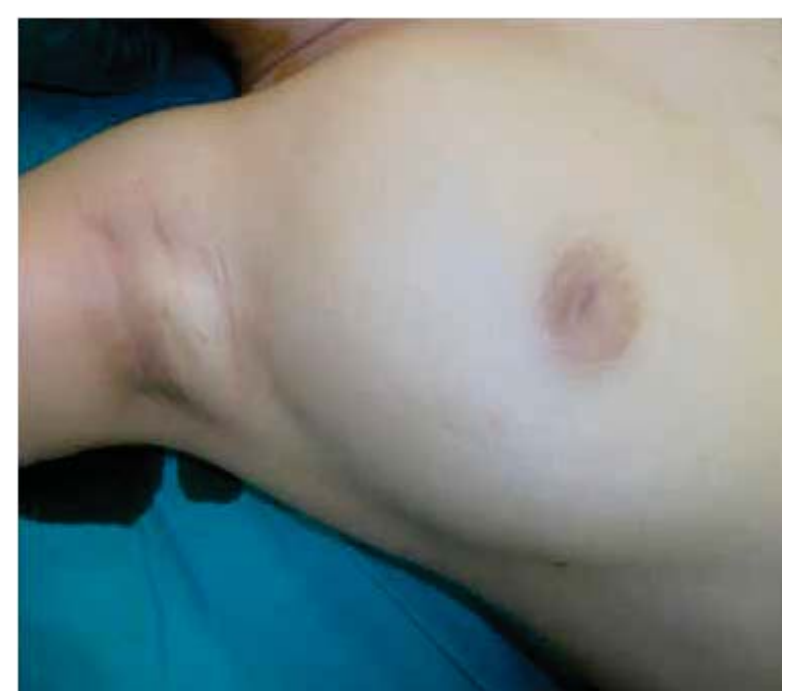

Resim1. Sağ aksiller ektopik meme dokusnun pre operatif görünümü

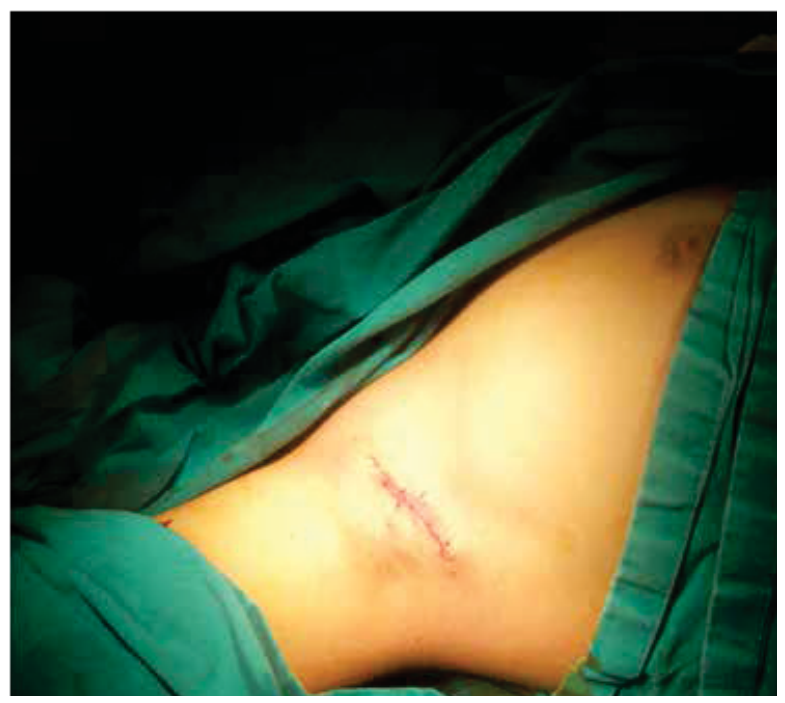

Resim 2. Post operatif aksillanın görünümü 


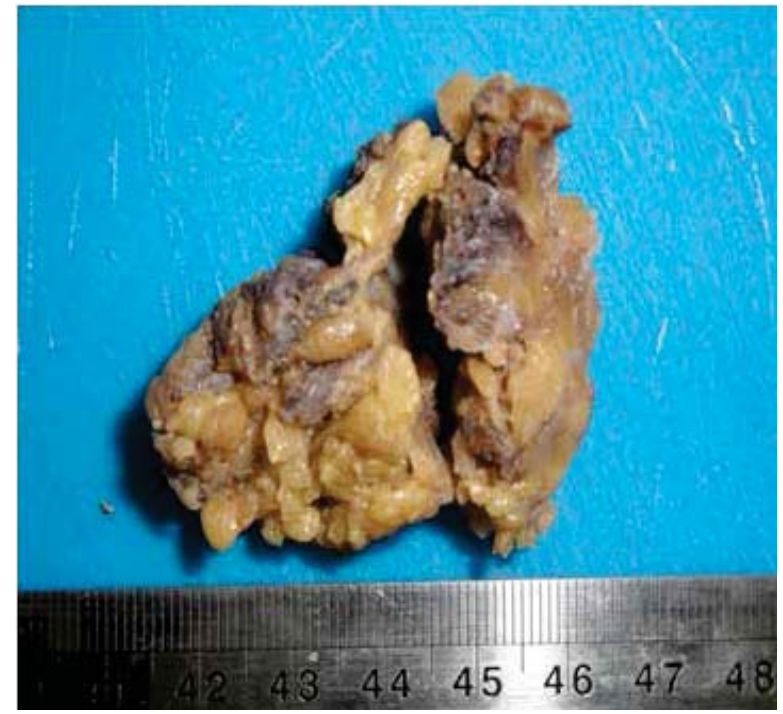

Resim 3. Speysmenin fiksasyon sonrası görünümü ve boyutu

Hastanın bilateral meme muayenesi normaldi. Ultrasonografide bilateral memeler normalken, sağ aksillada sınırları tam ayırdedilemeyen, kistik olmayan, klinik bilgi ışığında meme dokusu ile uyumlu olabilecek $1 \mathrm{~cm}$ lik bir doku tarifi vardı. Hastanın kitle muayenesinde, areola yada meme başına benzeyen bir yapı yoktu. Has-

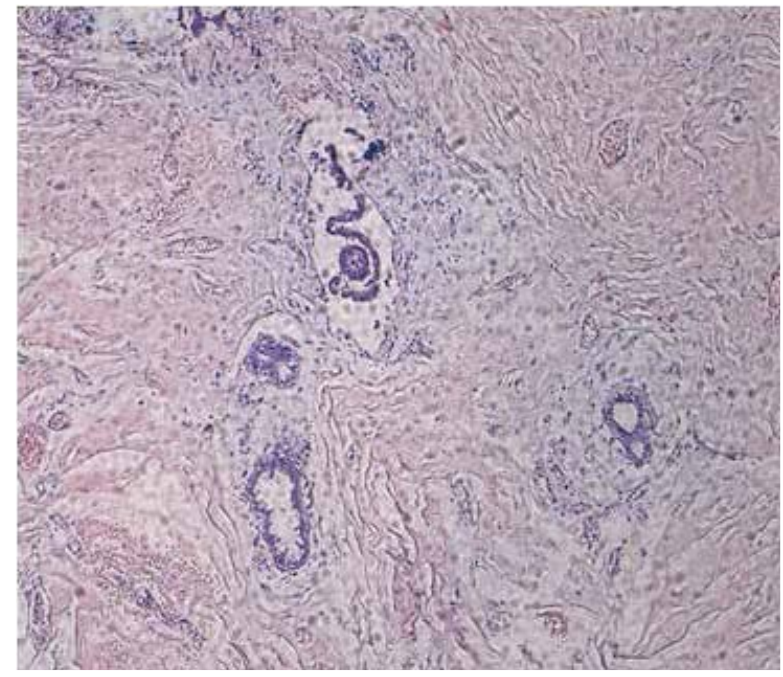

Resim 4. H\&E Ile, 5x100 büyütmede histopatolojik görünüm. tanın estetik görünüm kaygısı ve hareket kısıtlılığını kaldırmak için tanı ve tedavi amaçlı total eksizyonel biopsi yapıldı Eksizyonda, yaklaşık 4 cm'lik kitle etrafindaki bir miktar yağı ı dokuda eksize edildi ve eksizyon sonrası cilt anatomik yapıya uygun olarak kapatıldı (Resim 2). Kitlenin speysmen hazırlığında fiksasyon sonrası yağlı doku ve kitle ayırımı barizdi (Resim3). Kitlenin histopatolojik incelemesinde, fibrokistik hastalıkla uyumlu aksesuar meme dokusu sonucu elde edildi: Kesitlerde meme dokusu ile birlikte yoğunluğu artmış, hücreden fakir hiyalinize bağ doku alanlar içerisinde, lümenleri iki sıra epitelle döşeli duktuslar görülmekteydi (Resim 4). Hastanın 1 yıllık periyodik takiplerinde nüks, hareket kısıtlılığı yada estetik bir probleme rastlanmadı.

\section{TARTIŞMA}

Embriyonik dönemin 5. haftasında simetrik olarak epidermisden kalınlaşıp band şeklinde aksilladan kasık bölgesine doğru meme çizgisi denilen oluşum meydana gelir. 16. gebelik haftasında bu çizginin toraks kısmı mezenşime doğru invajine olur, diğer kısımlar atrofiye olur, epitelial tomurcuklardan dallanmalar meydana gelir. Laktofer kanallar küçük bir epitel çukura açılır ve doğum sonrası meme başına doğru gelişim devam eder. Meme çizgisi bu şekilde atrofiye olmazsa, en sık aksillada olmasına rağmen meme çizgisi boyunca aksilladan kasığa kadar herhangi bir yerde aksesuar meme ve/veya meme başı dokusu oluşur $(1,12)$.

Aksesuar meme dokusunda; normal meme dokusunda görülebilen fibroadenom, fibrokistik hastalık (13), filloides tümör (14), paget hastalı̆̆ı (15), mastit (10), apseler ve meme kanseri (16) gibi hastalıklar görülebilir. Literatürde lenfatik malformasyon veya lipoma gibi yanlış teşhis ve tedavi alan vakalarda vardır $(10,11)$. Aksesuar meme dokusu, özellikle ter bezlerine yakınsa yanlış tanı alması yaygındır (17). Aksesuar meme dokusunun tanIsı, genellikle gebelik yada menstrüel sikluslerle siklik değişiklik gösteren kitlenin şüphe üzerine mamografi çekilmesi, iğne biopsisi yapılması veya cerrahi biopsi sonucu tanınmasıyla konulur (18). 
Aksesuar meme dokusundaki şişlik, ağrı, doku irritasyonunda artş ve süt salgılanması, hormonal stimülasyonun arttı̆ı menarş, gebelik ve emzirme durumlarında belirginleşir (19). Literatürde aksesuar meme vakaları genelde erişkin yaşlarda olup (13-16) menarştan hemen sonra olan vakalar daha nadirdir. Bizim vakamızda 12 yaşında sağ koltuk altında kitle ile müracat eden, menarşdan sonra bir yıl içinde kitleye bağlı hareket kısıtlılığı ve terlemeyle artan ağrıları olan bir hasta idi.

Olgumuza yapılan ultrasonografide literatür vakalarında olduğu gibi artmış ekotekstür ve doku kalılaşması $(2,20)$ dışında, klinik şüphemiz olan aksesuar memeyi tam destekleyecek açık bir sonuç yoktu. Semptomatik aksiller aksesuar meme dokusunda tedavi seçimi total cerrahi eksizyondur $(2,19,20)$. Bizde hastamızda hareket kısıtlılığı yapan ve zaman zaman ağrıya neden olan bir aksiller kitleyi total olarak çevresinedeki sağlam doku ile birlikte, aksesuar meme şüphesiyle eksize ettik, histopatolojik sonuçlada kesin tanıyı koyduk. Ayrıca, olgumuzda tespit edilen aksesuar meme dokusundaki fibrokistik hastalık (13); aksesuar memede nadiren tespit edilen bir patolojidir.

Sonuç olarak; pubertal dönemde, menarşla birlikte semptomatik hale gelen aksiller bölge ve süt çizgisi hattındaki kitlelerde, hastanın yanlış tanı ve tedaviye maruz kalmaması için, aksesuar meme dokusu ayırıcı tanıda düşünülmelidir ve tedavisi eksizyonel biopsi olmalıdır.

\section{KAYNAKLAR}

1. Harris JR, Lippman ME, Morrow M, OsborneCK. Diseases of the breast, 2nd ed. Philadelphia, PA: Lippincott Williams \& Wilkins; 2000: 1-14.

2. Jordan K, Laumann A, Conrad S, Medenica M. Axillary mass in a 20-year-old woman: diagnosis axillary accessory breast tissue. Arch Dermatol. 2001;137(10): 1367-72.

3. Scanlan KA, Propeck PA. Accessory breast tissue in an unusual location. AJR. 1996;166(2): 339-40.

4. Lopes G, DeCesare T, Ghurani G, Vincek V, Jorda M, Glück $\mathrm{S}$, Silva O. Primary ectopic breast cancer presenting as a vulvar mass. Clin Breast Cancer. 2006;7(3): 278-9.
5. Senatore G, Zanotti S, Cambrini P, Montroni I, Pellegrini

A, Montanari E, Santini D,Taffurelli M. Ectopic breast fibroadenoma. G Chir. 2010; 31(3): 96-9.

6. Wang JJ, Yeung L, Taur CP, Sy LB, Chou TY, Leu FJ. Axillary supernumerary breast in a female adolescent: report of one case. Acta Paediatr Taiwan. 2005;46(4): 235-8.

7. Leung W, Heaton JPW, Morales A. An uncommon urologic presentation of a supernumerary breast. Urology. 1997;50(2): 122-4.

8. Alghamdi H. Accessory breasts: When to excise? Breast J. 2005;11(2): 155-7.

9. Down S, Barr L, Baildam AD, Bundred N. Management of accessory breast tissue in the axilla. Br J Sur. 2003;90(10): 1213-4.

10. DeCholnoky T. Accessory breast tissue in the axilla. NY State J Med. 1951;51(1): 2245-8.

11. Greer KE. Accessory axillary breast tissue. Arch Dermatol. 1974;109(1): 88-9.

12. Sadler TW. Langman's Medical Embryology. 8th ed. Philadelphia, Pa: Lippincott Williams\&Wilkins. 2000; 408-10.

13. Hassim AM. Bilateral fibroadenoma in supernumerary breasts of the vulva. J Obstet Gynaecol Br Commonw. 1969;76(3): 275-7.

14. Saleh HA, Klein LH. Cystosarcoma phyllodes arising synchronously in right breast and bilateral axillary ectopic breast tissue. Arch Pathol Lab Med. 1990;114(6): 624-6. 15. Kao GF, Graham JH, Helwig EB. Paget's disease of the ectopic breast with the underlying intraductal carcinoma: report of a case. J Cutan Pathol. 1986;13(1): 59-66.

16. Caceres M, Shih J, Eckert M, Gardner R. Metaplastic carcinoma in an ectopic breast. South Med J. 2002;95(4): 462-66.

17. Gutermuth J, Audring H, Voit C, Haas N. Primary carcinoma of ectopic axillary breast tissue. J Eur Acad Dermatol Venereol. 2006;20(2): 217-21.

18. Giron GL, Friedman I, Feldman S. Lobular carcinoma in ectopic axillary breast tissue. Am Surg. 2004;70(4): 312-5. 19. Lesavoy MA, Gomez-Garcia A, Nejdl R, Yospur G, Syiau TJ, Chang P. Axillary breast tissue: clinical presentation and surgical treatment. Ann Plast Surg. 1995;35(4): 356-60. 20. Kilic A, Kilic A, Emsen IM. Accessory axillarybreast tissue. Ann Plast Surg. 2001;46(6):657. 